\title{
多職種参加型心不全ワークシート導入前後における リハビリテーションの効果
}

 \\ 大塚 進, ${ }^{5}$ 加藤真帆人 ${ }^{2}$, 奥村 恭男 $^{2}$, 平山 篤志 $^{2}$
}

\begin{abstract}
多職種参加型心不全ワークシートを作成し運用した. 対象は, 平成 23 年 2 月から 5 月に心不全で当院循環 器内科病棟に入院した患者 25 名をコントロール群とし, 6 月から 10 月に入院した患者 20 名を介入群とし た. 各群間の患者背景因子に有意差は認めなかった. 各歩行開始日, および入院期間において介入群が有意 に短縮しており，経過中に有害事象は認めなかった．退院時 6 分間歩行距離は，有意差は認めないものの介 入群で延長傾向にあった．病期により分類し多職種が記入できるワークシートを作成したことにより情報の 共有化, 早期からの離床が可能になった。早期からの離床は十分な注意が必要であり, 理学療法士によるモ ニタリングの徹底, 多職種の視点からの評価と情報共有が重要であると考えられた. 社会の高齢化と共に, 再入院の多い心不全患者の高齢化が進む中で, 今後も早期からの心臓リハビリテーションの可能性について 研究が必要である.
\end{abstract}

KEY WORDS: heart failure, early ambulation, cardiac rehabilitation

\section{I.はじめに}

平成 24 年版高齢社会白書によると, 本邦に抢ける 65 歳以上の高齢者人口は, 過去最高の 2,975 万人となり, 総 人口に占める割合 (高齢化率) も $23.3 \%$ となった ${ }^{1)}$. 加齢に 伴い血管系も老化し, 動脈硬化が原因となる虚血心疾患 の増加に加えて, 心肥大, 拡張能の低下, 弁の変性によ る弁膜疾患, 刺激伝導系の異常などこれらの病態を背景 とした心不全が増加している，高齢者にとって治療のた めの過度な安静は身体的・精神的デコンディショニングな どの廃用症候群を招く危険性がある。2007 年に改定され た本邦の心血管疾患におけるリハビリテーションに関す るガイドラインは, 心不全の運動療法の適応となるの は, 安定期にあるコントロールされた患者となってい る. 2012 年に改定された心血管疾患におけるリハビリ テーションに関するガイドラインは, 急性心不全に対す る運動療法として, 血行動態が安定し安静時の症状がな ければ低強度の運動療法が可能であると改定された。し かし, 心不全患者にとっての入院早期の心肺運動負荷試 験は時期的に困難であることが多い。また，心不全患者

${ }^{1}$ 日本大学医学部附属板橋病院リハビリテーション科 ( ⿳ $173-$ 8610 東京都板橋区大谷口上町 30-1), ${ }^{2}$ 日本大学医学部循環器内 科, ${ }^{3}$ 日本大学医学部附属板橋病院看護部, ${ }^{4}$ 日本大学医学部附属 板橋病院栄養科, ${ }^{5}$ 日本大学医学部附属板橋病院薬剂部

本論文は第 26 回日本冠疾患学会学術集会, 2012 年 12 月・東京 にて発表した.

2013.08.10 受付, 2013.12.09 受理

doi: 10.7793/jcoron.19.13-00026
は罹患期間が長いことももともとの運動耐容能が低いた め客観的なリハビリ効果が測定困難な症例が多いこと， 高齢者の比率が高いため特徵的な重複障害のある症例が 多い。このような理由もあり, 早期からの心臟リハビリ テーションはまだ確立されていない。しかし, 心不全増 悪患者においても, 入院早期からの安全で包括的な心臓 リハビリテーション介入の必要性があると考えられる. 介入方法としては, 急性期心不全治療と共に, 廃用症候 群の予防, 早期離床, 塩分 - 水分管理, 薬効の理解や服薬 管理, 運動方法の指導, 精神的サポート, 日常生活指 導, 患者・家族の教育・指導, 退院・社会復帰に向けた社 会資源の活用など多職種の包括的な観点が必要である. 心不全患者は病態が多様であるため, クリニカルパスの ような画一的な管理が困難であることから，我々は多職 種参加型の心不全ワークシートを作成し, 導入前後のリ ハビリテーションの効果について検討した.

\section{II. 対 象}

平成 23 年 2 月から 5 月に急性心不全・慢性心不全急性 増悪の診断で当院循環器内科病棟に入院した患者 25 名 (男性 15 名, 女性 10 名) をコントロール群とし, 平成 23 年 6 月から 10 月に入院した患者 20 名 (男性 13 名, 女性 7 名)を介入群とした。症例は連続症例であり, 救命救急セ ンターに入院した症例は除外した。本研究は, 当院の臨 床研究審査会の承認を受け(承認番号 RK-110318-13), へ ルシンキ宣言に準じ患者に対する説明を行い書面にて同 意を得た。 
J Jpn Coron Assoc 2014; 20: 181-187

Table 1 Classification according to the AHF stage

\begin{tabular}{lll}
\hline \multicolumn{2}{l}{ STAGE } & \multicolumn{1}{c}{ Hemodynamics } \\
\hline I & Super acute & Under mechanical support (NIPPV, PCPS, IABP, etc.) \\
II & Acute & - Disappearance of orthopnea \\
& $\cdot$ Continuous inotropic drip \\
III & Recovery & Disappearance of a volume overload \\
IV & Preparation for discussion & The HF was compensated. Discharge was pending due to social reasons or test schedules \\
\hline
\end{tabular}

\section{III. 方 法}

各群において, 心不全の原因 (高血圧, 虚血性心疾患, 弁膜症, 特発性), Clinical Scenario(CS), 合併症(糖尿 病, 脂質異常症, 腎不全, 慢性肺疾患), 入院時 NYHA (New York Heart Association) 分類, NT-proBNP 值 (中央值 と 25〜 75\%タイルを記載), 超音波による心機能(LVDd: left ventricular enddiastolic diameter, LVDs: left ventricular endsystolic diameter, EF: ejection fraction), 入院期間, リハ ビリテーションにおける各歩行開始日 $(50 \mathrm{~m}$ 歩行, $100 \mathrm{~m}$ 歩行, $200 \mathrm{~m}$ 歩行), 最終到達レベル, 退院時 6 分間歩行 距離, 有害事象について評価した. 統計解析は, 2 群間比 較には, $\chi^{2}$ 検定, Mann Whitney's U test を用い解析し, NT-proBNP值は四分位法で表した。解析ソフトは JMP(r)9.0.2SASinstitute inc. を使用し, 統計学的有意差は $\mathrm{p}<0.05$ とした.

\section{1. 血行動態に基づく病期定義}

当院では, 心不全治療中の血行動態に基づき, 病期を 分類した (Table 1). 人工呼吸器, 適応補助換気 ASV (adaptive servo ventilation) 等を持続的に使用している状態 を超急性期, 起座呼吸が消失するが, 容量負荷が残存し ている状態, または, 強心剤などの持続点滴により循環 動態が維持されている状態を急性期, 容量負荷が改善 し, 持続の強心剂点滴から離脱できている状態を回復 期, 日常生活が可能であるが, 検査などで入院の継続が 必要な状態を退院準備期として定義した。

2. ワークシート

ワークシートは薬剤師の報告に多く, 安全で効率的な 業務改善, モニタリング項目の標準化などに効果を認め ている2,3). 池末らは薬剤管理指導業務の質的向上と効率 化を両立させるためにワークシートを作成し, 薬剤管理 指導業務の標準化が可能になったと報告している4).

当院で使用しているワークシートを Table 2 に示す. 病 期ごとにステージ分類を行い, 活動制限区分を設けてい る. 通常の日数で管理するクリニカルパスとは異なり, 日数ではなく医師が評価した血行動態を基準として安静 度を判断する。また, 医師, 理学療法士, 看護師, 管理 栄養士, 薬剤師の各職種の記入欄を設け, 病期ごとに記 入をすることが可能となっている. 医師は, 血行動態, 投薬開始の検討, 検査・各科への依頼, 各部門の経過確認
など全体を統括する，理学療法士は，全体の経過を確認 しながら, 血行動態を確認, 投薬状況, 看護部門からの 生活活動レベルの問題点などを把握し, 入院前の運動能 力, 活動状況, 家屋環境の確認を行い, 病期ごとに, 離 床, $50 \mathrm{~m}$ 歩行, $100 \mathrm{~m}$ 歩行, $200 \mathrm{~m}$ 歩行と運動負荷をか け, 循環動態の変化を確認する.リハビリテーション中 のモニタリングの指標は European Society of Cardiology (ESC)の Working Group の勧告5)を参考に作成し, 運動療 法の中止, 変更の基準とした (Table 3). 看護師は病識の 確認, 内服アドヒアランスの評価, 心不全パンフレット の配布, 患者教育, 入院中の精神的サポート, シャワー 浴時の血行動態評価を行い, 退院準備期までに血圧や体 重生活の自己管理の指導を行う。管理栄養士は, 入院前 の食事の把握, 塩分, 水分制限を含めた栄養指導を主に 行い, 薬剤師は入院時内服薬の確認, 内服アドヒアラン スの評価, 患者の教育を行う。多職種が記入でき, 1 枚の 用紙を使用するため, 治療経過, 離床の進み具合, 問題 点などの情報を多職種間で共有することが可能となった.

\section{IV. 結 果}

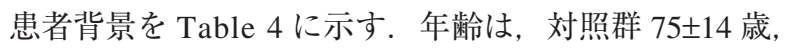
介入群 $72 \pm 10$ 歳で各群間に有意差を認めなかった。心 不全の原因としては, 高血圧性が多く4〜 5 割を占め, 次に虚血性, 弁疾患, 特発性となった。合併症として は, 糖尿病が各群共に 3 割を占め, 脂質代謝異常, 腎不 全, 慢性肺疾患が続いていた。 入院時の New York Heart Association 分類は III 度が 5 割, IV 度は約 4 割を占めてお り, 入院時の NT-proBNP值は各群間に差を認めなかっ た. 入院時心臓超音波による心機能評価では, LVDdには 差を認めなかったが, LVDs, LVEF は有意差を認めた.

各歩行開始日および入院期間を Fig. 1 に示す. $30 \mathrm{~m}$ 歩 行開始は対照群 $13.6 \pm 2.0$ 日, 介入群は $4.7 \pm 2.0$ 日, $50 \mathrm{~m}$ 歩 行開始日は対照群 $15.7 \pm 2.3$ 日, 介入群は $5.3 \pm 2.0$ 日, $100 \mathrm{~m}$ 歩行開始日は対照群 $16.8 \pm 1.6$ 日, 介入群 $6.2 \pm 1.7$ 日, $200 \mathrm{~m}$ 歩行開始日は対照群 $24.2 \pm 1.8$ 日, 介入群は $8.0 \pm 1.8$ 日, 入 院期間は対照群 $32 \pm 3.6$ 日, 介入群は $20.6 \pm 2.2$ 日であり, 各歩行開始日，および入院期間において介入群が有意に短 縮しており, 経過中に両群共に有害事象は認めなかった.

退院時の到達レベルを Fig. 2 に示す. 多くの症例が院内 歩行自立まで到達したものの, 立位レベル, $100 \mathrm{~m}$ 歩行, 
Table 2 Heart failure work sheet

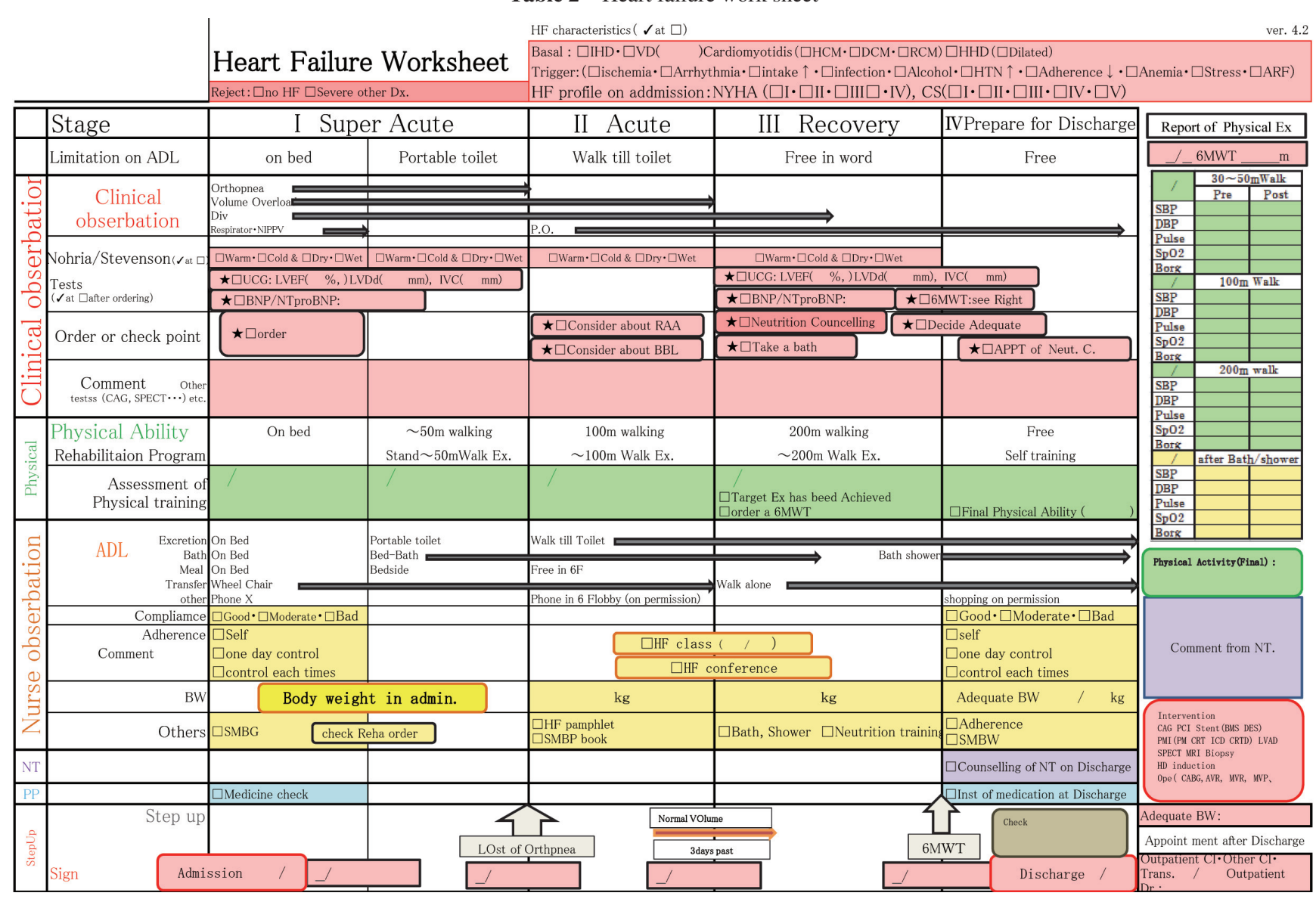

Table 3 Monitoring index during the rehabilitation (modified from ${ }^{1)}$ )

1. Marked dyspnea or fatigue (Borg scale of $\geq 14$ )
2. Increase in respiratory rate of $\geq 40 / \mathrm{min}$ during exercise
3. Pulse pressure reduction
4. Reduction in blood pressure by $\geq 10 \mathrm{mmHg}$ during exercise
5. Increased supraventricular or ventricular ectopic beats during exercise
6. Perspiration, paleness or disturbance of consciousness
7. Subjective symptoms (continuous fatigue, increase in Borg scale of $\geq 2$ after the same degree exercise)
8. Weight gain ( $\geq 2 \mathrm{~kg}$ increase/week)
9. Increase in heart rate of $\geq 10 / \mathrm{min}$ at rest or after the same degree exercise
10. Elevated BNP levels of $\geq 100 \mathrm{pg} / \mathrm{ml}$ from the last measurement
11. Worsening edema

$200 \mathrm{~m}$ 歩行レベルに留まった症例も認められた。 これは, 元々の ADL が低下している症例であった.

退院時 6 分間歩行距離の結果を Fig. 3 に示す. 対照群平 均 $306 \pm 88.8 \mathrm{~m}$, 介入群 $359 \pm 96.9 \mathrm{~m}$ であり, 有意差は認め ないものの介入群で延長傾向にあった.

\section{V. 考察}

日本の高齢化は進んでおり, 平成 24 年版高歯社会白書 によると, 65 歳以上の高齢者人口は, 過去最高の 2,975
万人となり, 高齢化率(総人口に占める割合) も $23.3 \%$ (前 年 $23.0 \%$ ) となった ${ }^{1)}$. 加齢に伴い血管系は老化し, 動脈 硬化が原因となる虚血心疾患の増加に加えて, 心肥大, 拡張能の低下, 弁の変性による弁膜疾患, 刺激伝導系の 異常などこれらの病態を背景とした心不全が増加してい る.また, 呼吸障害や脳血管疾患, 認知機能低下, 運動 器障害などの問題を抱えている高齢者特有の重複障害を 呈している症例も多い.

高齢患者の入院に関する研究で, 前本らは 75 歳以上の 
J Jpn Coron Assoc 2014; 20: 181-187

Table 4 Baseline demographics and clinical characteristics

\begin{tabular}{|c|c|c|c|}
\hline & Control $(n=25)$ & Intervention $(\mathrm{n}=20)$ & $P$ value \\
\hline Age (years) & $75 \pm 14$ & $72 \pm 10$ & n.s. \\
\hline \multicolumn{4}{|l|}{ Causal factors $(\%)$} \\
\hline Hypertension & 44 & 50 & \multirow[t]{4}{*}{ n.s. } \\
\hline Ischemic heart disease & 40 & 30 & \\
\hline Valvular heart disease & 24 & 10 & \\
\hline Idiopathic dilated cardiomyopathy & 16 & 10 & \\
\hline \multicolumn{4}{|l|}{ Clinical Scenario (CS) (\%) } \\
\hline CS1 & 48 & 25 & \multirow[t]{3}{*}{$\mathrm{P}<0.001$} \\
\hline $\mathrm{CS} 2$ & 36 & 65 & \\
\hline $\mathrm{CS} 3$ & 16 & 10 & \\
\hline \multicolumn{4}{|l|}{ Other diseases $(\%)$} \\
\hline Diabetes mellitus & 32 & 35 & \multirow[t]{4}{*}{ n.s. } \\
\hline Dyslipidemia & 20 & 15 & \\
\hline Renal dysfunction & 16 & 25 & \\
\hline Chronic lung disease & 12 & 10 & \\
\hline \multicolumn{4}{|l|}{ NYHA (\%) } \\
\hline III & 56 & 50 & \multirow[t]{2}{*}{ n.s. } \\
\hline IV & 38 & 40 & \\
\hline NT-proBNP (pg/ml) & $4186(1985-5681)$ & $6709(3979-15041)$ & $\mathrm{P}=0.15$ \\
\hline \multicolumn{4}{|l|}{ Echocardiographic parameter } \\
\hline LVDd (mm) & $54 \pm 10$ & $61 \pm 7$ & n.s. \\
\hline LVDs (mm) & $40 \pm 12$ & $49 \pm 9$ & $\mathrm{P}=0.04$ \\
\hline $\operatorname{LVEF}(\%)$ & $48 \pm 18$ & $39 \pm 13$ & $\mathrm{P}=0.03$ \\
\hline
\end{tabular}

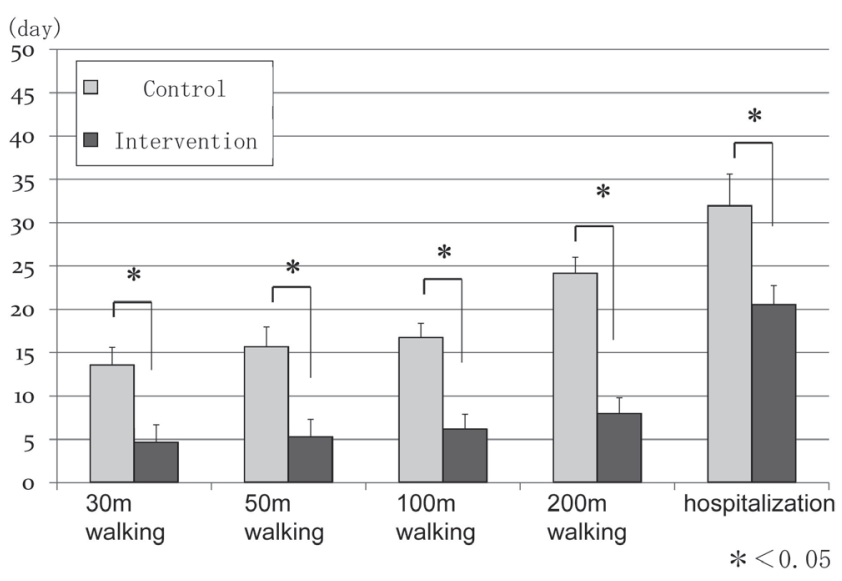

Fig. 1 Start of walking and hospitalization.

高齢肺炎患者の ADL 低下に影響を与える要因について検 討を行い, ADL 低下の要因として安静臥床期間に関して は長くなる程 ADL が低下しており, 安静臥床期間が精神 症状や誤與にも関係していると報告している6).

加齢による筋力低下もあり，高齢者の身体機能の低下 は個人差によるばらつきは多くなるものの生理学的な変

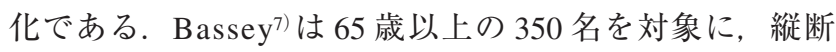
的に 4 年後および 8 年後に筋力, 肩関節可動域, ADL, 健康状態などについて調查している. 8 年後には体重は $2 \mathrm{~kg}$ 減少し, 筋力は年に $2 \%$ ずつ減少が認められたと報告

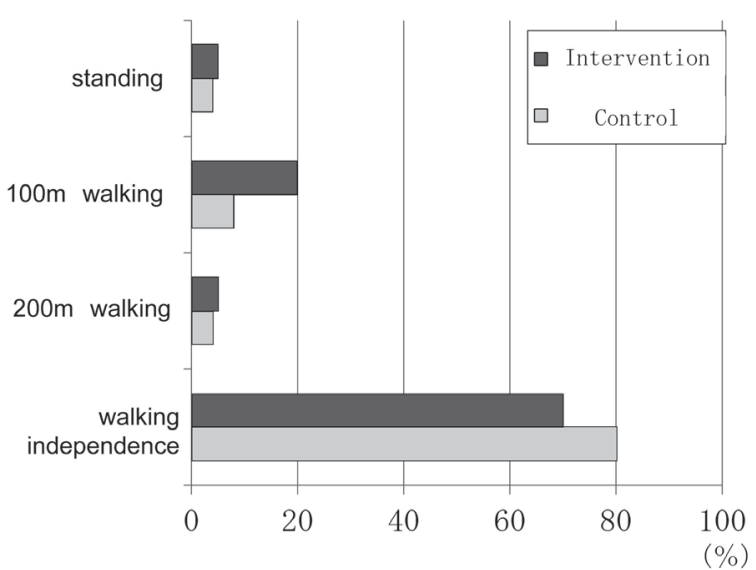

Fig. 2 Arrival level at discharge.

している

高齢者が心不全で入院すると加齢の影響に加え, 治療 のための安静臥床が身体機能に影響を及ぼす。さらに, 安静臥床が長期化すると廃用性筋萎縮が顕著となる。卧 床と筋力に関する研究はさまざまな報告がある。ベッド レスト研究によれば Ohira ら ${ }^{8)}$ は 6 度の頭低位での 4 力月 のベッドレストにより, タイプI 線維の横断面積減少がす すみ，その数も減少すると報告している．また，Gogia ら99 健常男性を 5 週間の徹底した臥床状態におき, 臥床前後 の筋力を等速性筋力測定器で測定し比較した結果による 
(m)



Fig. 3 Six minute walk distance at discharge.

と，低下率は膝関節伸展 19\%，足関節底屈 $26 \%$ としてい る。また，酒井ら $\left.{ }^{10}\right)$ は，膝関節手術の 23 名の男女 $(50$ 73 歳)を対象として, 術後 1 週間未満の臥床でも健側の大 腿四頭筋等尺性収縮筋力は半分にも減少すると報告して いる。，心不全患者の筋萎縮や骨格筋の変化は，罹患期間 の長期化による廃用症候群に加え, 未梢循環不全(低酸 素), タンパク質の異化充進, アポトーシス, 酸化ストレ ス，神経体液性因子などの各種要因が関与していると報 告されている11).

安静臥床による座位バランスに関する報告もある，倉 松ら ${ }^{22)}$ は療養高齢者の垂直位を調べるために, 長期療養 高齢者を対象に健常高齢者と健常若年者を対象として, 座位で状態が自分でまっすぐな状態(垂直位)にあると判 断した角度と実際の垂直位との前後方向の角度のずれを 調べた。その結果, 長期療養高齢者の垂直位の知覚は健 常高齢者掞よび，健常若年者に比べてばらつきが大きく どちらかというと後方に偏位する傾向があり, 起居動作 能力のレベルが高いほど角度のずれが小さくなる傾向が みられたと報告している。

上記の報告のように，社会が高齢化し，心不全患者の 高齢化も進み, 急性増悪時の治療のための安静期間が長 くなることで, 患者の身体的・精神的デコンディショニン グが進み, さらに心不全特有の筋肉の変化が加わること で, ADL や QOL の低下につながり退院も困難になる.

これを防ぐには安全な早期離床が必要となる。しか し, 心不全の運度療法は「心疾患に扔けるリハビリテー ションに関するガイドライン 2007 年改訂版」によれば, 運動療法の適応となるのは, 安定期にあるコントロール された心不全で NYHA II〜III 度の症例であり，「安定期に ある」とは, 少なくとも過去 1 週間において心不全の自覚 症状(呼吸困難, 易疲労性など) および身体所見(浮腫, 肺 うっ血など)の増悪がないこととされていた．2012年の改 定では，急性心不全の心血管疾患リハビリテーションの 意義は,「早期離床による過剩な安静の弊害を予防, 迅速
かつ安全な退院と社会復帰へのプランを立案, 共有し, 実現すること，運動耐容能の向上により，QOLを改善さ せること, 患者教育と疾病管理により, 心不全の再発や 再入院を予防すること」と改定された，また，実際の運動 療法に関しても, 血行動態が安定し, 安静時の症状がな ければ静注薬投与中であっても低強度の理学療法・運動療 法が可能であり, ベッド上で四肢の屈伸運動，軽い抵抗 運動, ベッドサイドでの立位やつかまり立ち運動などを 行うとされた。しかし，心不全の急性期心臟リハビリ テーションにおける適切な運動負荷量などについての詳 細な研究は十分とはいえない。公不全の疾病管理の研究 では欧米で, 1990 年代半ばから介入研究が行われ，それ によると心不全は状態が安定してから退院後にかけての 疾病管理が重要となる。しかし, 入院期間の短縮化が進 む現在では，早期からの介入が必要となるだろう。疾病 管理の要点は, チーム医療, 退院時指導, フォローアッ プ, ガイドラインに沿った薬物療法, 十分な患者教育, 患者モニタリングによる心不全増悪の早期発見などがあ げられる13,14)。心不全はクリニカルパスのような日数での 管理が困難であることから，我々は血行動態に基づく病 期で分類しワークシートを作成した。 今回，心不全の急 性期患者に扔いて，心不全ワークシートを使用し，早期 離床に取り組むこと, 早期からの疾病管理を目的に多職 種での包括的な心臓リハビリテーションを提供すること を目的として介入を行った。

早期からの運動療法は重症例では十分な注意が必要で ある. American Heart Associationによる運動療法のリスク 分類においては, クラス Dの患者に対し, コンディショ ニング目的での活動は勧められないとされており，日常 活動は患者の主治医によって行われた個人の評価をもと に処方されるべきであるとしている15)。心機能低下例で は, ATレベル以上の運動強度では, 左室駆出率の低下を 来す例が多いことが知られており, ATレベル以下の運動 強度から開始し, 経過を見ながら負荷強度を漸増するこ とが望ましい。しかし，今回の対象者のように，急性期 治療を脱したばかりの患者や重症例では, 必ずしも運動 負荷試験が可能な患者ばかりではなく，その場合は心電 図や血圧をモニターしながら，低強度によるさまざまな 運動療法を工夫することになる16. ガ゙イドラインにおい ても(1)自覚症状, (2)体重増加傾向, (3)心拍数増加傾向, (4)血中 BNP 上昇傾向などをモニタリングの指標ととらえ ており，当院においてもワークシート上に理学療法士が 行った負荷に対する心電図, 血圧, 脈拍, Borg 指数, コ メントを記載する闌を設けており，運動療法の経過につ いて，医師が適宜確認することを可能とした．

心不全治療において疾病管理は重要な役割を果たして おり，その実現のためにはチーム医療が重要となる，厚 生労働省の「チーム医療の推進について」によると, チー 厶医療とは「医療に従事する多種多様な医療スタッフが 
各々の高い専門性を前提に, 目的と情報を共有し, 業務 を分担しつつも互いに連携・補完し合い，患者の状況に的 確に対応した医療を提供すること」としている ${ }^{17)}$. ワーク シートの作成にあたり数カ月前より医師, 看護師, 管理 栄養士, 薬剤師, 理学療法士でミーティングを重ね, 多 職種に必要な情報や項目を確認し, 記入しやすいワーク シートの作成を目標として作成した。多職種が記入しゃ すく 1 枚の用紙を使用することになり，情報の共有が容 易になったのではないかと考えられる.リハビリテー ションの依頼もワークシート上に記載されているため, 依頼忘れや依頼の遅延が減少している。また，治療の経 過についても確認が可能となり, 現在どのような治療が 行われているのか, 他の職種は何をしているのか, 何が 問題点になっているのか, 退院を考える時期なのか, 退 院にあたっての問題はないかなど細かい部分の漏れがな いように互いの職種が補完しあえるようになった。ワー クシート導入により, リハビリテーションでは各歩行開 始日, 在院日数は短縮し, 6 分間歩行距離は延長傾向に あった. 早期からの理学療法介入が可能となり, 無用な 臥床を短縮できたこと, メデイカルスタッフでも病期の 理解が可能となったことが結果につながったと考えられ る. 理学療法士の早期介入により危惧された有害事象の 発生は血行動態を基準として病期が分けられていたこ と, 理学療法士によるモニタリングの徹底, 多職種の視 点からの評価と情報共有が行われたために抑制されたの ではないかと考えられる。しかし，今回の研究では患者 数は少ないため, 今後も継続して有用性の検討を行う必 要があるものと考えられる. 高齢化が進み, 高齢の心不 全入院患者は増加傾向を辿ると推察され, 今後も様々な 方法で早期離床と疾病管理に取り組む必要性がある.

当院ではワークシート導入と同時にワークシートを補 う部分として, 心不全のカンファレンスを週 1 回開催し ている. 毎週水曜日, 14 時から 30 分間と時間を定め, 心 不全カンファレンス担当医師, 主治医グループ, 担当看 護師㧍よび担当グループ, 理学療法士, 薬剂師, メディ カルソーシャルワーカー, 在宅支援担当看護師, 臨床心 理士の多職種が参加して行っている. カンファレンスで はワークシート導入中の問題点, 各アドヒアランス, 転 院や退院を考えた際の問題点などが話し合われている. 主治医グループの医師から入院から現在までの治療経過 や問題点, 今後の方針などが話され, 看護師からは日常 生活上の問題点や疾病管理上の問題点, 家族構成, 看護 上の問題点などが話され, 薬剤師は入院以前の服薬のア ドヒアランスや理解度, 服薬管理の是非などが話され る. 理学療法士は入院以前の活動量, 活動範囲, 現在の 筋力や $\mathrm{ADL}$, 基本動作能力, 歩行能力などを報告する. 臨床心理士は重症心不全患者や移植待機患者などの心理 的ケアを行っており, 関わっている場合には現状の報告 を行い, 心不全に多く認められるうつ症状などが認めら
れ, 必要と判断されれば介入の依頼を主治医から行う. 患者の転帰としては, 退院か転院があり, 入院早期から 考えなければならない課題となっている.メディカル ソーシャルワーカーは社会資源の情報や利用方法, 転院 先の確保について, 在宅支援担当看護師は退院した場合 の医療的支援の何を提供する必要性があるのか, どのよ うな方法で行うのかについて検討される. 早期からワー クシート上での情報交換が可能となり, さらにカンファ レンスで詳細な情報交換が行われ，今後の方針も明確に なることから各職種が主治医を中心とした方向性を意識 しながら動くことが可能となる，その結果，無駄な情報 のやり取りや時間を省くことが可能となり, 退院や転院 についても早期に行うことが可能になったと考えられる.

\section{VI. まとめ}

高齢化社会が進み, 加齢による心不全患者も増加して いる. 入院した心不全患者に対する急性期からのリハビ リテーションの介入が必要とされるようになってきてい る. しかし, 心不全患者は, 複合的な問題を抱えている ことが多く，今回のような多職種によるプログラムを適 応できるかには不安もあったが, 病期で分類することに より早期からリハビリテーションの介入が可能であっ た．また， 1 枚のワークシートを使用することにより，他 職種の役割や情報の共有化が可能となり，有害事象も認 めなかった，再入院の多い心不全患者の高齢化が進む中 で今後も多職種による疾病管理と入院早期からの離床の 可能性について研究が必要である.

\section{文献}

1)平成 24 年版高齢社会白書. http://www8.cao.go.jp/kourei/ whitepaper/w-2012/zenbun/pdf/mokuji1.pdf

2) Suzuki Y, Yamamoto T, Nakane S, et al: Development and evaluation of supplementary sheet for preparation of anticancer agents - work sheets to support pharmaceutical management developed for outpatient cancer chemotherapy. Jpn J Pharm Health Care Sci 2009; 35: 729-737(in Japanese)

3) Shibata $Y$, Ikeda H, Fujiwara H, et al: Evaluation of a worksheet for monitoring adverse reactions during concurrent chemoradiation. Jpn J Pharm Health Care Sci 2007; 33: 159-165(in Japanese)

4) Ikesue $H$, Development of work sheets to provide efficient pharmaceutical care during cancer chemotherapy and their evaluation. Jpn j Pharm Health Care Sci 2006; 32: 1-12(in Japanese)

5) Working Group on Cardiac Rehabilitation \& Exercise and Physiology and Working Group on Heart Failure of the European Society of Cardiology. Recommendations for exercise training in chronic heart failure patients. Eur Heart J 2001; 22: $125-135$

6）前本英樹, 上村恭生, 木口和明, 他：高齢肺炎患者の ADL 低下に影響を与える要因の検討. 理学療法学 2007; 34: $16-20$ 
7) Bassey EJ: Longitudinal changes in selected physical capabilities: muscle strength, flexibility and body size. Age Ageing 1998; 27: 12-16

8) Ohira Y, Yoshinaga T, Nonaka I, et al: Histochemical responses of human soleus muscle fibers to long-term bedrest with or without countermeasures. Jpn J Physiol 2000; 50: 41-47

9) Gogia P, Schneider VS, LeBlanc AD, et al: Bed rest effect on extremity muscle torque in healthy men. Arch Phys Med Rehabil 1988; 69: 1030-1032

10）酒井直隆, 腰野富久, 岡本連三, 他 : 膝関節手術後の大 腿四頭筋筋力の回復過程. リ八医学 1991; 28: 601-606

11）沖田考一, 絹川真太郎, 筒井裕之：心不全における骨格 筋異常と筋仮説. 循環器内科 $2011 ; 69: 275-285$

12) Kuramatu $Y$, Maeda S, Shiomi T: Perception of verticality in the sitting position by the elderly with long-term care needs. Rigakuryoho Kagaku 2007; 22: 467-472(in Japanese)

13) Jaarsma $T$, Stewart S: Nurse-led Management programmes in heart failure.Caring for the heart failure patients, Ed by Stewart S, Moser DK, Thompson DR, Taylar\&Francis, London, 2004, pp169

14) Moser DK, Riegel B: Management of heart failure in the outpatient setting, In: Heart failure. A companion to Braunwald's heart disease, MannDL (Ed), Elsevier, Philadelphia, 2004, pp772

15) Fletcher GF, Balady GJ, Amsterdam EA, et al: Exercise standards for testing and training: a statement for healthcare professionals from the American Heart Association. Circulation 2001; 104: $1694-1740$

16）長山雅俊：心不全治療の適応と評価. 早期リハビリテー ション ICU と CCU 2011; 35: 757-763

17）厚生労働省 チーム医療の推進について(チーム医療の推 進に関する検討会報告書). http://www.mhlw.go.jp/ shingi/2010/05/dl/s0512-6g.pdf

\title{
Effects of cardiac rehabilitation in patients with acute heart failure using a multi-disciplinary work sheet for the Nichidai acute heart failure program
}

\author{
Rie Matsudo, ${ }^{1}$ Toshiyuki Ohya, ${ }^{2}$ Junko Yamada, ${ }^{3}$ Kumiko Kameyama, ${ }^{4}$ \\ Susumu Ootsuka, ${ }^{5}$ Mahoto Kato, ${ }^{2}$ Yasuo Okumura, ${ }^{2}$ and Atsushi Hirayama ${ }^{2}$ \\ ${ }^{1}$ Department of Rehabilitation, Nihon University Itabashi Hospital \\ ${ }^{2}$ Division of Cardiology, Department of Medicine, Nihon University School of Medicine \\ ${ }^{3}$ Department of Nursing, Nihon University Itabashi Hospital \\ ${ }^{4}$ Department of Nutrition, Nihon University Itabashi Hospital \\ ${ }^{5}$ Department of Pharmacy, Nihon University Itabashi Hospital
}

\begin{abstract}
Objective: The utility of a multi-disciplinary work sheet for the Nichidai acute heart failure (AHF) program was investigated in the AHF hospitalized patients. Methods and Results: The subjects were 45 patients with clinical diagnoses of AHF, who were admitted to Nihon University Itabashi Hospital from February 2011 to October 2011. Standard rehabilitation was performed in 25 patients (control group) and the remaining 20 (work sheet group) underwent rehabilitation according to the Nichidai AHF program multi-disciplinary work sheet. There were no differences in the baseline characteristics between the two groups. The start of each rehabilitation phase was significantly earlier (5.3 \pm 2.0 days vs $15.7 \pm 2.3$ days for $50 \mathrm{~m}, 6.2 \pm 1.7$ days vs $16.8 \pm 1.6$ days for $100 \mathrm{~m}$, and $8.0 \pm 1.8$ days vs $24.2 \pm 1.8$ days for $200 \mathrm{~m}$ walk training, $\mathrm{P}<0.05$ for each), and hospital stay shorter for the rehabilitation in the work sheet group than the control group $(20.6 \pm 2.2$ days vs $32.0 \pm 3.6$ days, $\mathrm{P}<0.05)$. Although no adverse events were observed in either group, the 6-min walk distance slightly improved in the work sheet group. Conclusions: The multidisciplinary work sheet helped share patient information, and shortened the hospitalization. Sharing patient information and a multi-disciplinary comprehensive management program are important for safely accomplishing early ambulation for the patients. Our data will drive the efforts to perform further studies on the impact of early cardiac rehabilitation for $\mathrm{AHF}$ patients.
\end{abstract}

KEY WORDS: heart failure, early ambulation, cardiac rehabilitation

J Jpn Coron Assoc 2014; 20: 181-187 